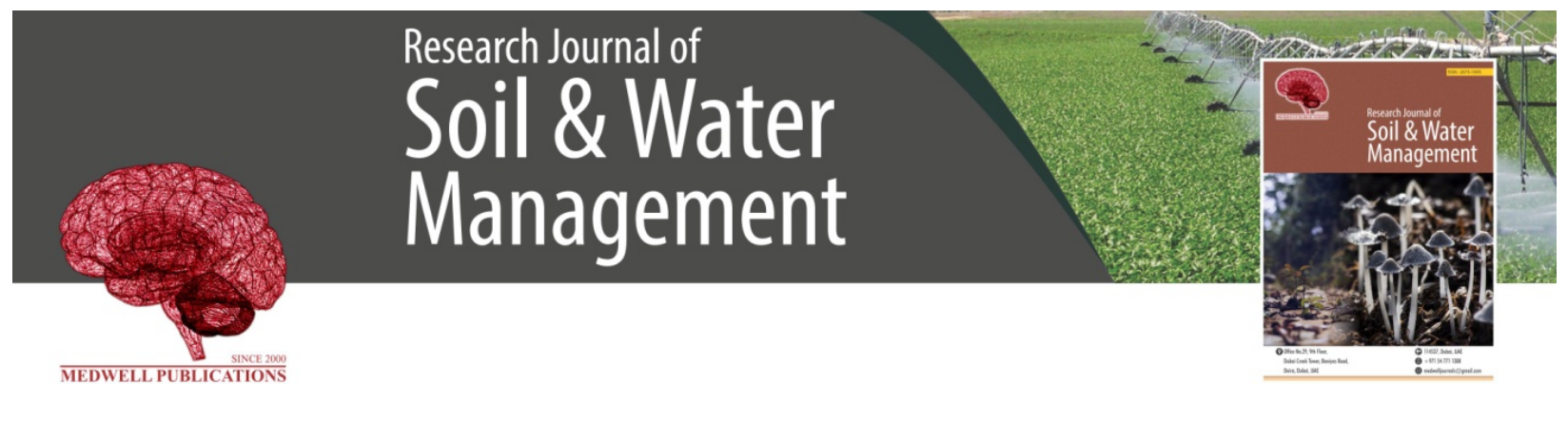

\title{
Subsurface Probe and Geophysical Analysis for Ground Water Flow Direction and Siting of Dumpsites in Orogun Main Town, Delta State of Nigeria
}

Oseji Otutu Julius

Department of Physics, Faculty of Science, Delta State University, Abraka, Nigeria

Key words: Global positioning system, meter tape, dumpsite, borehole, groundwater, contamination and orogun

\section{Corresponding Author:}

Oseji Otutu Julius

Department of Physics, Faculty of Science, Delta State University, Abraka, Nigeria

Page No.: 9-15

Volume: 14, Issue 2, 2020

ISSN: 2075-1095

Research Journal of Soil and Water Management Copy Right: Medwell Publications
Abstract: A study was carried out in Orogun main town in Ughelli North local government area of Delta state of Nigeria to determine the best locations for dumpsite and borehole for potable water supply. This was achieved by using the Global Positioning System (GPS) and the meter tape. The longitudes, latitudes and elevations of sixteen locations evenly distributed within Orogun main town were measured and recorded with the aid of the Global positioning system. Using the meter tape, the depths to water levels in the hand dug wells at the same locations were also measured. The water elevation contour map of Orogun town revealed that ground water flow direction is towards the North-Western part of the region. In the event of pollution, boreholes within the North-Western part of Orogun main town are prone to contamination. This is because any contaminant in the South, East, West and North-Eastern part of Orogun migrates and settles in the North-Western regions. Hence, dumpsites could be sited in the North-Western part while boreholes for potable water could be sited within the South, East and North Eastern part of Orogun main town in other to minimize groundwater contamination and hence avoid water borne diseases. The present study acts as a guide for the location of dumpsites and future exploration and exploitation of groundwater to avoid water borne diseases.

\section{INTRODUCTION}

Groundwater is an important source of water supply throughout the world. It is used in irrigation, industries, municipalities and rural homes. Cooling and air conditioning have made heavy demands on groundwater because of its characteristics uniformity in temperature ${ }^{[1,2]}$. Shortage of groundwater in areas where excessive withdrawals have occurred emphasize the need for accurate estimates of the available subsurface resources and the importance of proper planning to ensure the continued availability of water supplies ${ }^{[3-5]}$.

The subsurface zones in which all rock openings are filled with water is the saturated zone ${ }^{[6]}$. If a well is drilled downward into this zone, groundwater will fill the lower part of the well. The water level inside the well marks the upper surface of the saturated zone called the water table. However, if a well is drilled downward to a certain depth where the pore spaces of the material are filled with 
air or a mixture of air and water such zone is referred to as unsaturated or Vadose zone. The term unsaturated is applied because the pores are not filled with water.

As groundwater is being utilized, certain issues such as pollution or contamination arose. Since, water always flows from a region of higher head to a region of lower head $^{[3,7]}$. It is found that groundwater used within an area at a higher elevation directly affects the quality of water available to people living in region of lower water level ${ }^{[7,8]}$. To this end it becomes necessary to investigate the pattern in which ground water flows, so as to ascertain the pattern of distribution of contaminants hence proffer reliable recommendations.

\section{MATERIALS AND METHODS}

Geographical location of orogun maintown: The study area is located in Orogun municipality which is delineated by geographical co-ordinates of $\mathrm{N} 05^{\circ} 33^{\prime} \mathrm{E} 006^{\circ} 47^{\prime}$. The area is accessible through a major road network that runs from Abbi to Ughelli. The area is dominated by moderate vegetation cover and slight flat topography. Figure 1 is the base map of Orogun showing the points of the vertical electrical soundings and the position of the hand-dug wells. However, in this project, the hand-dug wells were utilized. Three major stages of field procedures were used.
The Global Positioning System (GPS) of type 300 was used to measure the longitude, latitude and surface elevations with respect to the mean sea level at sixteen locations evenly distributed within Orogun main town. The lowest surface within the earth is the mean sea level and all elevations were taken with respect to the mean sea level.

The GPS is a self-contained hand-held receiver designed for general purpose such as position locating and navigation. It has a built in antenna located at the top of the receiver, a black light display and keypad. It also operates with two AA batteries, inserted from the battery door found at the back of the receiver. The GPS will operate for up to $20 \mathrm{~h}$. Furthermore, the GPS uses magnetic North as a default reference for all navigation computation. This can be changed to true North, especially, if one is working with maps. It is also designed to interface with personal computers and other devices through the provided data port with the aid of a data cable. Figure 2 is the schematic diagram of GPS 300 showing the basic functional keys.

As the GPS searches for satellites, some of the small circles around the large circle will become black, indicating that the GPS is tracking that satellite and

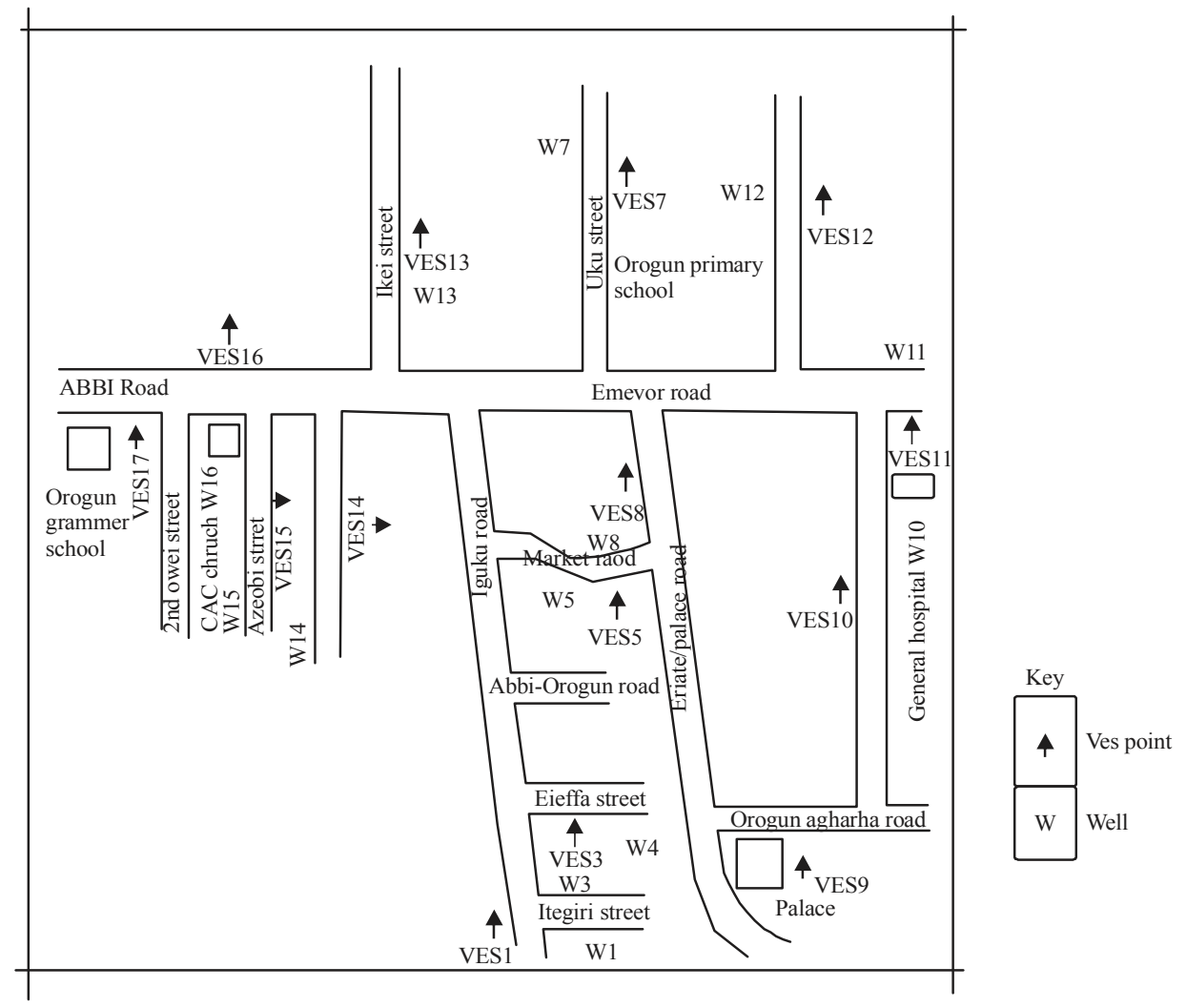

Fig. 1: Base Map of Orogun town, Ughelli North local government area of Delta state, Nigeria 


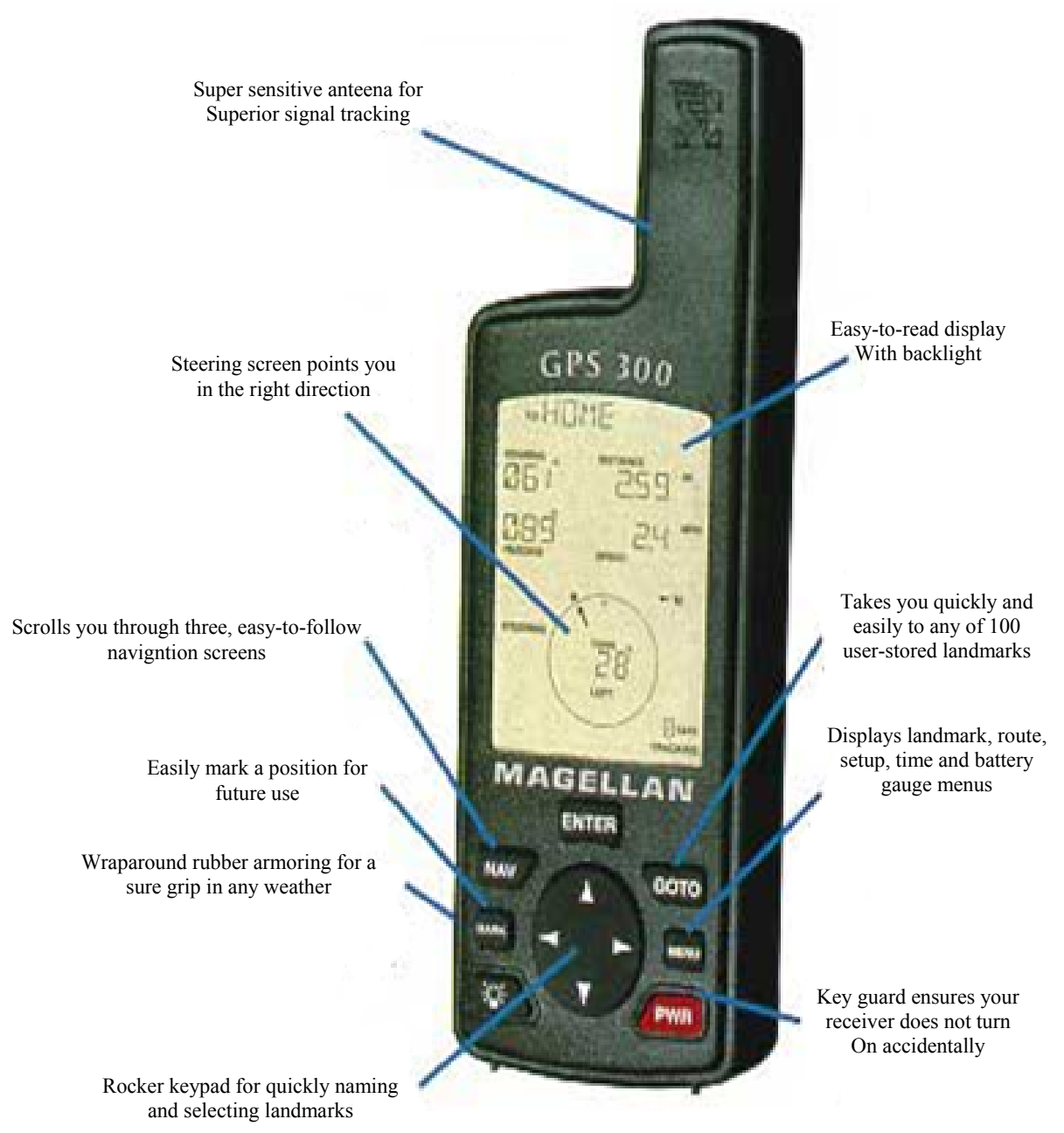

Fig. 2: Diagram of the Gps 300 showing the basic function keys

receiving information. The number at the bottom right hand corner of the screen displays how many satellites are being tracked. When the GPS has received positioning data from at least three satellites (approximately 2-3 min), it will begin computing a position based on the information it is receiving. As soon as a position fix is computed, the receiver switches to the navigation screen displaying the moving compass. The word "tracking" is displayed on the lower right corner indicating that the receiver is computing position and hence, the Latitude, Longitude and Elevation readings can be read directly from the display screen.

With the aid of a meter rule, the depths to the surface of the water in the hand dug wells were measured directly and recorded. The static water levels were obtained by subtracting the depth to water level in the hand dug well from the surface elevation:

$$
\mathrm{S}_{\mathrm{wL}}=\mathrm{E}-\mathrm{D}_{\mathrm{wL}}
$$

Where:

$\mathrm{E}=$ The surface elevation with respect to the mean sea level

$D_{\mathrm{WL}}=$ The depth from the surface of the earth to the water level in the hand dug wells

$\mathrm{S}_{\mathrm{wL}}=$ The static water level otherwise known as the true or uniform water level

\section{RESULTS AND DISCUSSION}

Results obtained from the field: Sixteen locations were surveyed during the research and the Latitudes, Longitudes, Elevations and depth to water level in hand dug wells were recorded. The Static Water Levels $\left(\mathrm{S}_{\mathrm{WL}}\right)$ were obtained for each of the locations as shown in Table 1. 
Res. J. Soil and Water Manage., 11 (2): 9-15, 2020

Table 1: Showing field data acquired for the latitudes, longitudes, elevations and depth to water level in hand dug wells as well as the calculated static water level

\begin{tabular}{|c|c|c|c|c|c|}
\hline Locations & Latitude & Longitude & Elevation E (m) & $\begin{array}{l}\text { Depth to water level } \\
\text { in hand dug well } \mathrm{D}_{\mathrm{wL}}(\mathrm{m})\end{array}$ & $\begin{array}{l}\text { Static water level } \\
\mathrm{S}_{\mathrm{WL}}=\mathrm{E}-\mathrm{D}_{\mathrm{WL}}(\mathrm{m})\end{array}$ \\
\hline Etegere way & $\mathrm{N}^{\circ} 35^{\circ} 39.122^{1}$ & $\mathrm{E} 006^{\circ} 09.269^{1}$ & 23 & 1.76 & 21.24 \\
\hline Sotton close & N05 $39.149^{1}$ & $\mathrm{E} 006^{\circ} 09.371^{1}$ & 25 & 2.73 & 22.27 \\
\hline Ojefia close & N05 $38.963^{1}$ & $\mathrm{E} 006^{\circ} 09.196^{1}$ & 23 & 2.34 & 20.66 \\
\hline Abbi-Orogun road & $\mathrm{N}^{\circ} 5^{\circ} 38.829^{1}$ & $\mathrm{E} 006^{\circ} 09.241^{1}$ & 20 & 1.12 & 18.88 \\
\hline Orogun market road & N05 $38.638^{1}$ & $\mathrm{E} 006^{\circ} 09.757^{1}$ & 20 & 1.15 & 18.85 \\
\hline Umoko street & $\mathrm{N} 05^{\circ} 38.587^{1}$ & $\mathrm{E} 006^{\circ} 09.470^{1}$ & 22 & 1.61 & 20.39 \\
\hline Uku street & $\mathrm{N}^{0} 5^{\circ} 38.425^{1}$ & $\mathrm{E} 006^{\circ} 09.551^{1}$ & 21 & 1.86 & 19.14 \\
\hline ErhetaStr/Palace road & $\mathrm{N} 05^{\circ} 38.497^{1}$ & $\mathrm{E} 006^{\circ} 09.319^{1}$ & 24 & 1.81 & 22.19 \\
\hline Orogun-Agbarh road & $\mathrm{N} 05^{\circ} 38.470^{1}$ & $\mathrm{E} 006^{\circ} 09.061^{1}$ & 22 & 2.25 & 19.75 \\
\hline Hospital road & $\mathrm{N} 05^{\circ} 38.285^{1}$ & $\mathrm{E} 006^{\circ} 09.224^{1}$ & 21 & 1.6 & 19.40 \\
\hline Emevor-Orogun road & $\mathrm{N} 05^{\circ} 38.039^{1}$ & $\mathrm{E} 006^{\circ} 09.224^{1}$ & 14 & 1.47 & 12.53 \\
\hline Okumere street & N05 $38.245^{1}$ & $\mathrm{E} 006^{\circ} 09.359^{1}$ & 20 & 2.19 & 17.81 \\
\hline Ikei street & N05 $38.505^{1}$ & $\mathrm{E} 006^{\circ} 09.615^{1}$ & 14 & 1.66 & 12.34 \\
\hline Azubi street & N05 $38.702^{1}$ & $\mathrm{E} 006^{\circ} 09.548^{1}$ & 15 & 1.91 & 13.09 \\
\hline Ovie street & $\mathrm{N} 05^{\circ} 38.767^{1}$ & $\mathrm{E} 006^{\circ} 09.585^{1}$ & 11 & 1.94 & 9.06 \\
\hline Orogun-Abbi road by CAC & $\mathrm{N} 05^{\circ} 38.769^{1}$ & $\mathrm{E} 006^{\circ} 09.711^{1}$ & 23 & 1.90 & 21.10 \\
\hline
\end{tabular}

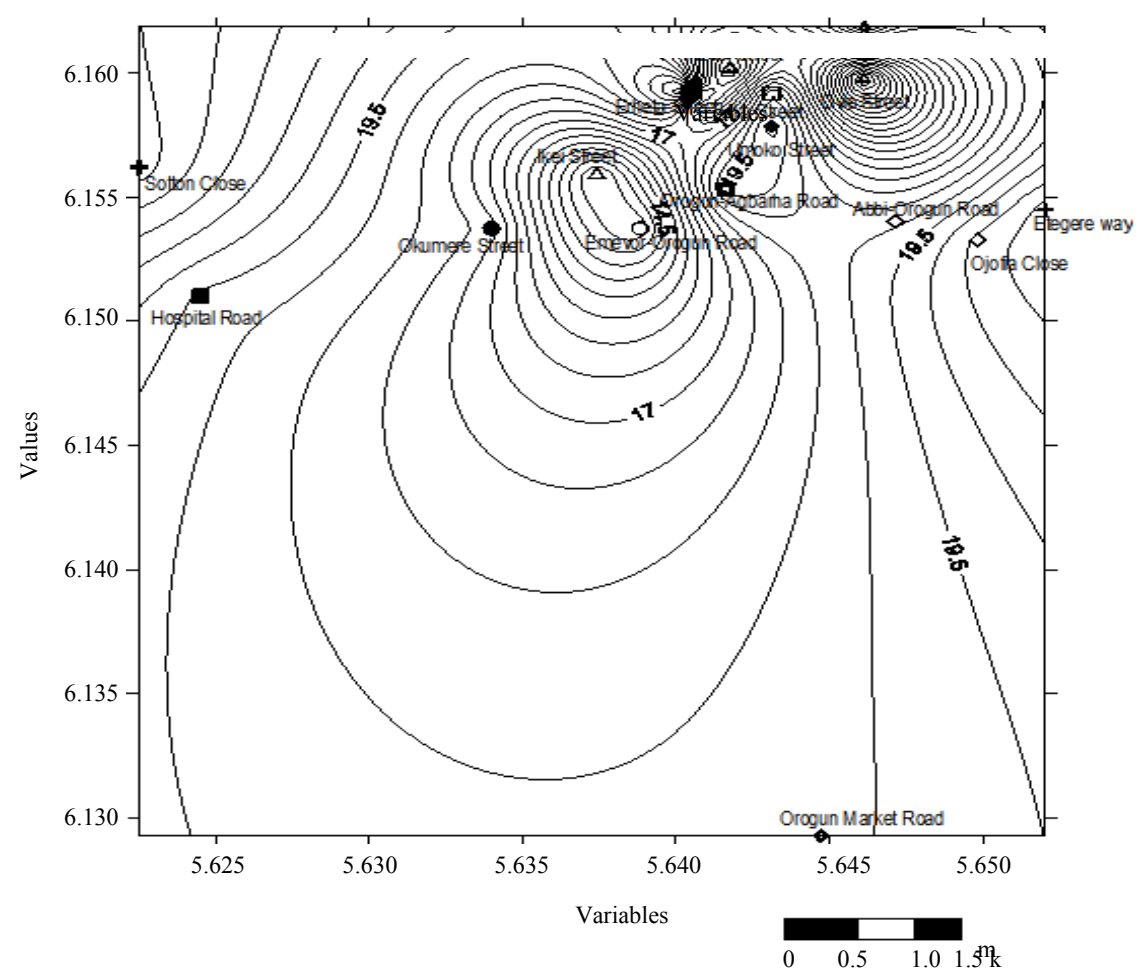

Fig. 3: Contour map of Orogun town

Interprtation and discussion of result: The values of the static water levels shown in Table 1 above were contoured on the map of Orogun town by joining equal values of static water levels and making sure that none of the lines overlapped or cut across each other. This was improved upon with the aid of surfer 8 software (computer package) as shown in Fig. 3.

According to Buddermeier and Schloss $^{[7]}$ groundwater flows from the highest value of the contour lines to the lowest values in a direction perpendicular to the contour lines as shown in Fig. 4.
The contour map of Orogun town using colours to represent the elevation of water as well as the wire frame of Orogun main town showing groundwater flow direction are shown in Fig. 5 and 6, respectively.

The water elevation contour map of Orogun town revealed that groundwater flow direction is towards the North-Western part of the region. It is therefore, recommended that dumpsites should be sited within the North-Western part of Orogun town to avoid groundwater contamination consequently; boreholes for potable water should be sited in the west, South, East and North-Eastern part of Orogun town. The knowledge of the direction of 


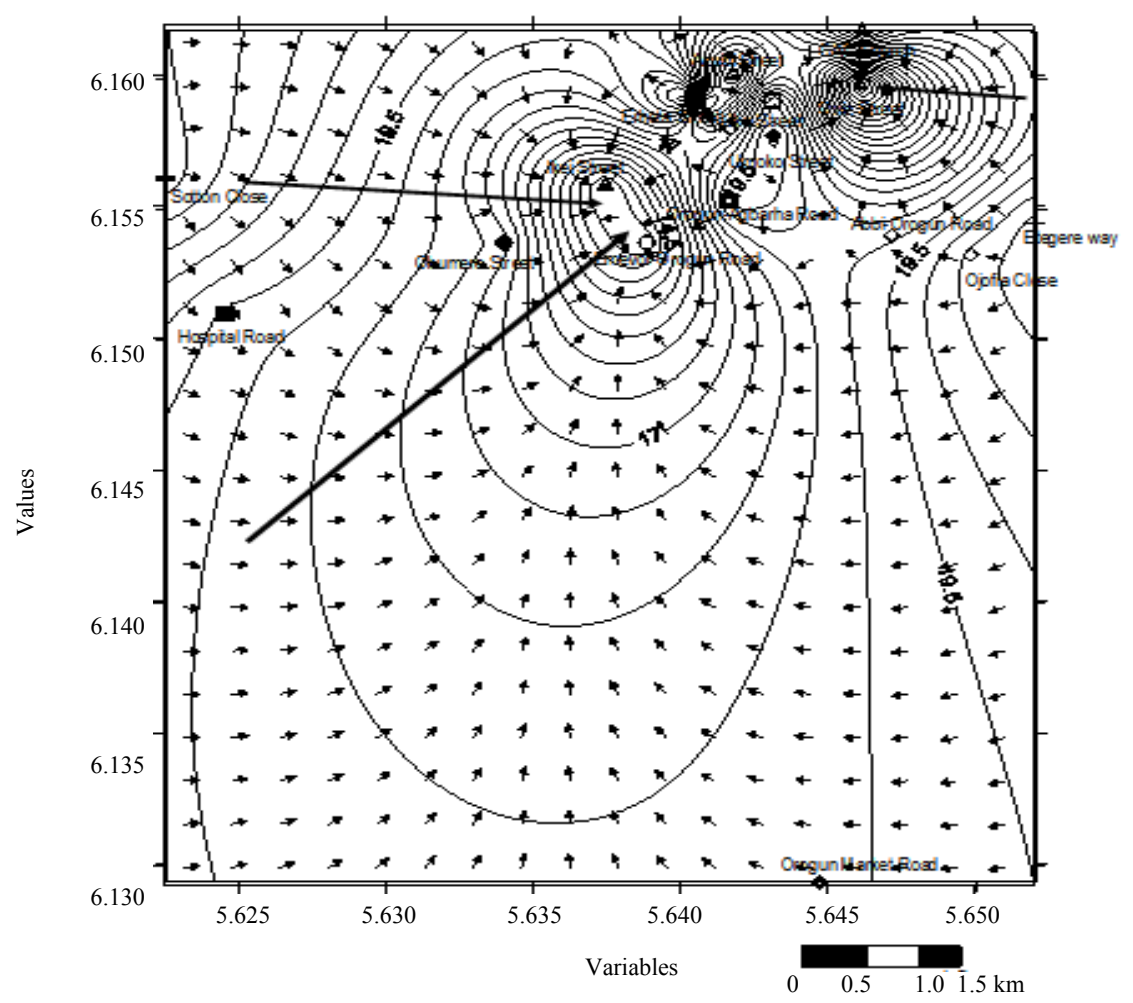

Fig. 4: Contour map of orogun main town showing groundwater flow direction in two dimensions using suffer 8 program

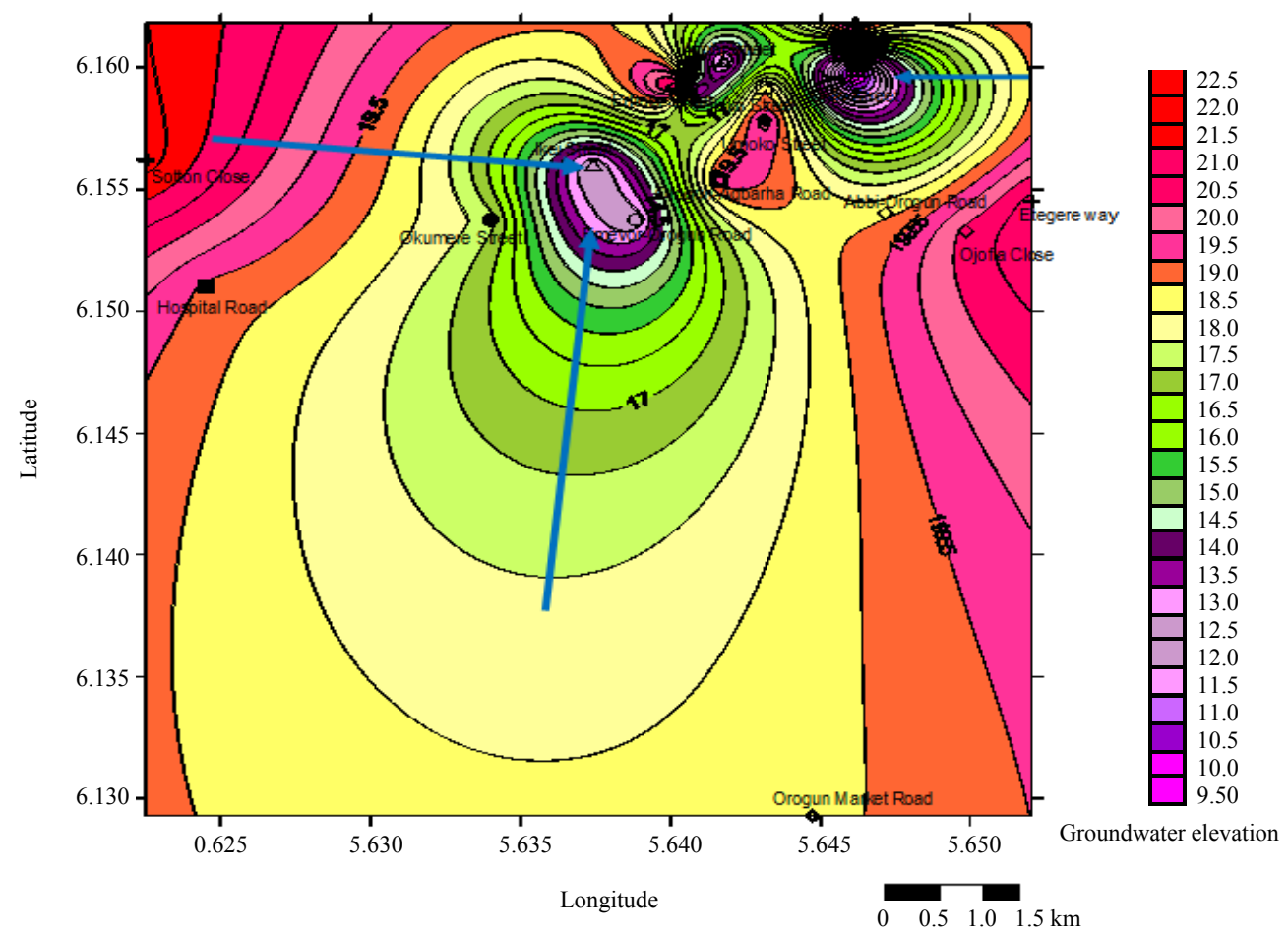

Fig. 5: Contour color of orogun main town showing groundwater flow direction in two dimensions using suffer 8 computer program 


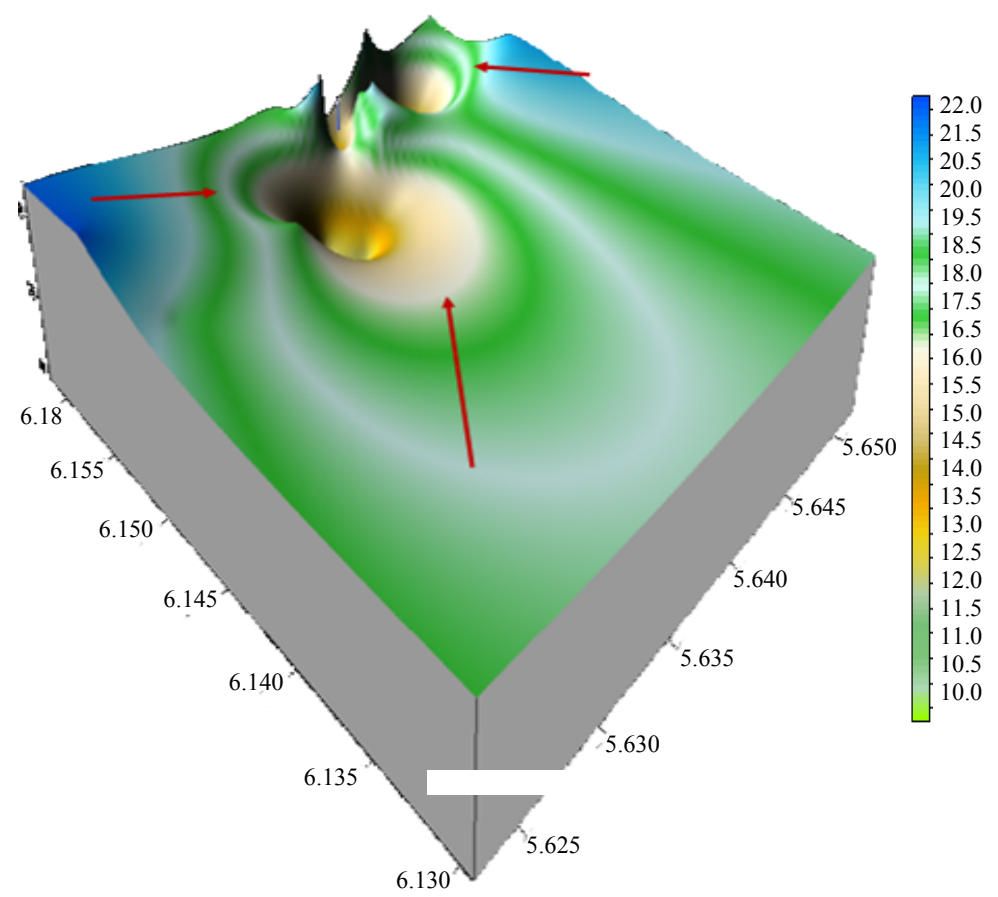

Fig. 6: Wire frame of orogun main town showing groundwater flow direction in three dimensions using suffer 8 computer program

flow of groundwater is very important as it will help groundwater developers in sitting boreholes for potable water. It is also important for locating dumpsites and septic tank (sock away) to avoid groundwater contamination.

\section{CONCLUSION}

The water elevation contour map of Orogun main town in Ughelli North local government area revealed that groundwater flow direction is towards the North-Western part of the region. Among the sources of groundwater pollution are leachates from dumpsites and the health of the inhabitants, stands at risk if leachates are allowed to communicate with groundwater.

Based on the flow pattern in Orogun main town, Dumpsites should be sited within the North-western part of the while boreholes for potable water should be sited in the West, South, East and North-Eastern part of Orogun town in order to minimize groundwater contamination by dumpsites.

\section{RECOMMENDATIONS}

From the research, groundwater flows toward the North-Western direction. Dumpsites therefore should be sited within the North-western part of
Orogun main town while boreholes for potable water should be sited in the West, South, East and North-Eastern part of the land in order to minimize groundwater contamination by dumpsites. The research did not only pave way for a clear picture of the flow system in Orogun main town but also recommends the area boreholes for potable water supply should be sited.

\section{REFERENCES}

01. Buddemeier, R.W. and J.A. Schloss, 2000. Groundwater storage and flow. http://www.kgs. ku.edu/HighPlains/atlas/apgengw.htm.

02. Etu-Efeotor, J.O. and E.G. Akpokodje, 1990. Aquifer systems of the Niger Delta. Nig. J. Mining Geol., 26: 279-284.

03. Hall, P. and J. Chan, 1996. Water Well and Aquifer Test Analysis. Water Resources Publications, Littleton, CO.

04. Huisman, L., 1966. Groundwater in Deltas. Proceedings of the Dacca Symposium on Scientific Problems of the Humid Tropical Zone Deltas and their Implications, February 24-March 2, 1964, UNESCO, Paris, France, pp: 157-168.

05. McWhorter, D.B. and D.K. Sunada, 1977. Ground-Water Hydrology and Hydraulics. Water Resources Publications, Littleton, CO., Pages: 146. 
06. Oseji, J.O., E.A. Atakpo and E.C. Okolie, 2005. Geoelectric investigation of the aquifer characteristics and groundwater potential in Kwale, Delta state, Nigeria. J. Applied Sci. Environ. Manage., 9: 157-160.

07. Oseji, J.O., M.B. Asokhia and E.C. Okolie, 2006.. Determination of roundwater potential in Obiaruku and environs using surface geoelectric sounding. The Environmentalist, 26: 301-308.
08. Plummer, C.C., D. McGeary and D.H. Carlson, 2003. Physical Geology. 9th Edn., McGraw-Hill, New York.

09. Todd, D.K., 1980. Groundwater Hydrology. John Willey Sons Inc., New York, Pages: 535.

10. Ward, A.D. and S.W. Trimble, 2004. Environmental Hydrology. CRC Press, Boca Raton, FL., pp: 62. 